of VEGF receptors causes lung cell apoptosis and emphysema. $J$ Clin Invest 2000;106:1311-1319.

19. Ferrara F, D'Adda D, Falchi M, et al. The macrophagic activity of patients affected by pneumonia or chronic obstructive pulmonary disease. Int J Tissue React 1996;18:109-114.

20. Hodge S, Hodge G, Scicchitano R, et al. Alveolar macrophages from subjects with chronic obstructive pulmonary disease are deficient in their ability to phagocytose apoptotic airway epithelial cells. Immunol Cell Biol 2003;81:289-296.

21. Kirkham PA, Spooner G, Rahman I, et al. Macrophage phagocytosis of apoptotic neutrophils is compromised by matrix proteins modified by cigarette smoke and lipid peroxidation products. Biochem Biophys Res Commun 2004;318:32-37.

22. Prieto A, Reyes E, Bernstein ED, et al. Defective natural killer and phagocytic activities in chronic obstructive pulmonary disease are restored by glycophosphopeptical (inmunoferon). Am J Respir Crit Care Med 2001;163:1578-1583.

23. Finney-Hayward TK, Russell REK, Kon OM, Fitzgerald MF, Barnes PJ, Donnelly LE. Decreased phagocytotic activity of monocyte-derived macrophages in patients with COPD [abstract]. Proc Am Thorac Soc 2005;2:A17.

24. Fujita M, Shannon JM, Irvin CG, et al. Overexpression of tumor necrosis factor-alpha produces an increase in lung volumes and pulmonary hypertension. Am J Physiol Lung Cell Mol Physiol 2001;280:L39-L49.

25. Kinchen JM, Cabello J, Klingele D, et al. Two pathways converge at CED-10 to mediate actin rearrangement and corpse removal in C. elegans. Nature 2005;434:93-99.

26. Ogden CA, deCathelineau A, Hoffmann PR, et al. C1q and mannose binding lectin engagement of cell surface calreticulin and CD91 initiates macropinocytosis and uptake of apoptotic cells. J Exp Med 2001; 194:781-795.

27. Gardai SJ, Xiao YQ, Dickinson M, et al. By binding SIRPalpha or calreticulin/CD91, lung collectins act as dual function surveillance molecules to suppress or enhance inflammation. Cell 2003;115:13-23.

28. Honda Y, Takahashi H, Kuroki Y, et al. Decreased contents of surfactant proteins A and D in BAL fluids of healthy smokers. Chest 1996;109: 1006-1009.

29. Guo X, Lin HM, Lin Z, et al. Surfactant protein gene A, B, and D marker alleles in chronic obstructive pulmonary disease of a Mexican population. Eur Respir J 2001;18:482-490.

30. Hoffmann PR, deCathelineau AM, Ogden CA, et al. Phosphatidylserine (PS) induces PS receptor-mediated macropinocytosis and promotes clearance of apoptotic cells. J Cell Biol 2001;155:649-659.

31. Leverrier Y, Ridley AJ. Requirement for Rho GTPases and PI 3-kinases during apoptotic cell phagocytosis by macrophages. Curr Biol 2001;11: 195-199.

32. Tosello-Trampont AC, Nakada-Tsukui K, Ravichandran KS. Engulfment of apoptotic cells is negatively regulated by Rho-mediated signaling. J Biol Chem 2003;278:11772-11779.

33. Morimoto K, Janssen WJ, Fessler MB, McPhillips KA, Borges VM, Bowler RP, Xiao YQ, Kench JA, Henson PM, Vandivier RW. Lovastatin enhances clearance of apoptotic cells (efferocytosis) with implications for chronic obstructive pulmonary disease. J Immunol 2006; 176:7657-7665.

34. Jacobson JR, Barnard JW, Grigoryev DN, et al. Simvastatin attenuates vascular leak and inflammation in murine inflammatory lung injury. Am J Physiol Lung Cell Mol Physiol 2005;288:L1026-L1032.

35. Fessler MB, Young SK, Jeyaseelan S, et al. A role for hydroxy-methylglutaryl coenzyme a reductase in pulmonary inflammation and host defense. Am J Respir Crit Care Med 2005;171:606-615.

36. Lee JH, Lee DS, Kim EK, et al. Simvastatin inhibits cigarette smokinginduced emphysema and pulmonary hypertension in rat lungs. Am J Respir Crit Care Med 2005;172:987-993.

37. Fadok VA, Bratton DL, Konowal A, et al. Macrophages that have ingested apoptotic cells in vitro inhibit proinflammatory cytokine production through autocrine/paracrine mechanisms involving TGF-beta, PGE2, and PAF. J Clin Invest 1998;101:890-898.

38. McDonald PP, Fadok VA, Bratton D, et al. Transcriptional and translational regulation of inflammatory mediator production by endogenous TGF-beta in macrophages that have ingested apoptotic cells. J Immunol 1999;163:6164-6172.

39. Huynh ML, Fadok VA, Henson PM. Phosphatidylserine-dependent ingestion of apoptotic cells promotes TGF-beta1 secretion and the resolution of inflammation. J Clin Invest 2002;109:41-50.

40. Hoffmann PR, Kench JA, Vondracek A, et al. Interaction between phosphatidylserine and the phosphatidylserine receptor inhibits immune responses in vivo. J Immunol 2005;174:1393-1404.
41. Voll RE, Herrmann M, Roth EA, et al. Immunosuppressive effects of apoptotic cells. Nature 1997;390:350-351.

42. Delacourt C, Le Bourgeois M, D'Ortho MP, et al. Imbalance between $95 \mathrm{kDa}$ type IV collagenase and tissue inhibitor of metalloproteinases in sputum of patients with cystic fibrosis. Am J Respir Crit Care Med 1995; 152:765-774

43. Golpon HA, Fadok VA, Taraseviciene-Stewart L, et al. Life after corpse engulfment: phagocytosis of apoptotic cells leads to VEGF secretion and cell growth. FASEB J 2004:18:1716-1718.

44. Morimoto K, Amano H, Sonoda F, et al. Alveolar macrophages that phagocytose apoptotic neutrophils produce hepatocyte growth factor during bacterial pneumonia in mice. Am J Respir Cell Mol Biol 2001; 24:608-615.

45. Kanazawa H, Hirata K, Yoshikawa J. Imbalance between vascular endothelial growth factor and endostatin in emphysema. Eur Respir J 2003; 22:609-612.

46. Plantier L, Marchand-Adam S, Marchal-Somme J, et al. Defect of hepatocyte growth factor production by fibroblasts in human pulmonary emphysema. Am J Physiol Lung Cell Mol Physiol 2005;288:L641-L647.

47. Massaro D, Massaro GD, Baras A, et al. Calorie-related rapid onset of alveolar loss, regeneration, and changes in mouse lung gene expression. Am J Physiol Lung Cell Mol Physiol 2004;286:L896-L906.

48. Aoshiba K, Nagai A. Differences in airway remodeling between asthma and chronic obstructive pulmonary disease. Clin Rev Allergy Immunol 2004;27:35-43.

\section{Statins Enhance Clearance of Apoptotic Cells through Modulation of Rho-GTPases}

Konosuke Morimoto, William J. Janssen, Michael B. Fessler, Yi Qun Xiao, Kathleen A. McPhillips, Valeria M. Borges, Jennifer A. Kench, Peter M. Henson, and R. William Vandivier

Division of Pulmonary Sciences and Critical Care Medicine, University of Colorado Health Sciences Center; and Department of Immunology, National Jewish Medical and Research Center, Denver, Colorado

Clearance of apoptotic cells (efferocytosis) is a key modulator of the inflammatory response, and is dysregulated in several chronic inflammatory lung diseases, including chronic obstructive pulmonary disease and cystic fibrosis. Rho-GTPases are signaling molecules that differentially regulate efferocytosis: RhoA and its downstream effector Rho kinase inhibit efferocytosis, whereas Rac-1/Cdc42 stimulate it. Statins are 3-hydroxyl-3methylglutaryl coenzyme A (HMG-CoA) reductase inhibitors with broad antiinflammatory effects, largely based on their ability to block prenylation and membrane localization of RhoGTPases, including RhoA. Therefore, we hypothesized that statins would enhance efferocytosis by inhibiting RhoA. In vitro, lovastatin increased efferocytosis by both human and murine macrophages. The positive effect of lovastatin on efferocytosis was prevented by mevalonate, farnesylpyrophosphate, and geranylgeranylpyrophosphate, and was mimicked by specific inhibitors of farnesyltransferase and geranylgeranyltransferase. These results suggested that lovastatin acted by inhibiting HMG-CoA reductase and subsequent downstream prenylation events. In support of this notion, lovastatin decreased membrane localization of RhoA, but had no effect on expression of macrophage efferocytosis receptors. To determine whether lovastatin enhanced efferocytosis in vivo, mice were challenged intratracheally with apoptotic thymocytes, in the presence and absence of lovastatin or the Rho kinase inhibitor (Y-27632), and clearance of these apoptotic thymocytes was assessed. Both lovastatin and Y-27632 enhanced efferocytosis in vivo. These findings suggest that statins enhance efferocytosis in vitro and in vivo, and may ultimately play 
an important therapeutic role in diseases where efferocytosis is impaired and inflammation is dysregulated.

Conflict of Interest Statement: K.M. does not have a financial relationship with a commercial entity that has an interest in the subject of this manuscript. W.J.J. does not have a financial relationship with a commercial entity that has an interest in the subject of this manuscript. M.B.F. is the recipient of a Pfizer Atorvastatin Research Award totaling $\$ 100,000$. Y.Q.X. does not have a financial relationship with a commercial entity that has an interest in the subject of this manuscript. K.A.M. does not have a financial relationship with a commercial entity that has an interest in the subject of this manuscript. V.M.B. does not have a financial relationship with a commercial entity that has an interest in the subject of this manuscript. J.A.K. does not have a financial relationship with a commercial entity that has an interest in the subject of this manuscript. P.M.H. does not have a financial relationship with a commercial entity that has an interest in the subject of this manuscript. R.W.V. is the recipient of the Pfizer Atorvastatin Research Award totaling $\$ 100,000$. He is also the recipient of a grant from GlaxoSmithKline totaling $\$ 100,000$.

(Received in original form March 17, 2006; accepted in final form March 28, 2006) Supported by the Pfizer Atorvastatin Research Award.

Correspondence and requests for reprints should be addressed to R. William Vandivier, M.D., Division of Pulmonary Sciences and Critical Care Medicine, University of Colorado Health Sciences Center, 4200 East Ninth Ave, C272, Denver, CO 80220. E-mail: bill.vandivier@uchsc.edu

Proc Am Thorac Soc Vol 3, 2006

DOI: $10.1513 /$ pats.200603-073MS

Internet address: www.atsjournals.org

\section{Prostacyclin Synthase in Smoking- related Lung Disease}

\author{
S. Patrick Nana-Sinkam, Jong Deog Lee, Robert Stearman, \\ Seiichiro Sakao, Sylk Sotto-Santiago, Norbert F. Voelkel, and \\ Mark W. Geraci
}

Division of Pulmonary Sciences and Critical Care Medicine and COPD Center, University of Colorado Health Science Center, Denver, Colorado; and College of Medicine, Gyeongsang National University, Chinju, South Korea

Background: Prostacyclin is a major product of the cyclooxygenase (COX) pathway with both potent vasodilatory and antimitogenic properties. Previous studies have demonstrated an increase in cyclooxygenase $2(\mathrm{COX}-2)$, prostaglandin $\mathrm{E}_{2}$, cytosolic phosphoplipase A2 $\left(\mathrm{cPLA}_{2}\right)$, and vascular endothelial growth factor (VEGF), but decreased prostacyclin synthase $\left(\mathrm{PGI}_{2} \mathrm{~S}\right)$ expression within lung tumors. Lung-specific overexpression of $\mathrm{PGI}_{2} \mathrm{~S}$ has protective effects in both chemical- and tobacco smokeinduced murine models of lung tumorigenesis. Lastly, $\mathrm{PGI}_{2} \mathrm{~S}$ expression within lung tumors may correlate with survival. Here, we hypothesize that an imbalance in $\mathrm{COX}-2, \mathrm{PGE}_{2}$, and $\mathrm{PGI}_{2} \mathrm{~S}$ may be important to the pathogenesis of other smoking-related lung diseases such as chronic obstructive pulmonary disease and that tobacco smoke may alter $\mathrm{PGI}_{2} \mathrm{~S}$ expression. Design: We evaluated $\mathrm{PGI}_{2} \mathrm{~S}$ expression in both normal and emphysematous human lung tissue samples by: (1) immunohistochemistry, (2) quantitative PCR, (3) Western analysis, and (4) both 6-keto PGF1 $\alpha$ (the stable metabolite of prostacyclin) and $\mathrm{PGE}_{2}$ levels by ELISA. In addition, we treated primary human pulmonary microvascular endothelial cells (HPMVEC) with varying concentrations of cigarette smoke extract (CSE). Treated cells were assessed for $\mathrm{PGI}_{2} \mathrm{~S}, \mathrm{COX}-2$, VEGF, and cPLA 2 gene expression, and 6Keto-PGF1 $\alpha$ and $\mathrm{PGE}_{2}$ levels. Measurements and Results: In this study, we observed that human lung emphysema tissue exhibited lower $\mathrm{PGI}_{2} \mathrm{~S}$ expression in the endothelium than normal lung tissue. Furthermore, in HPMVEC, CSE suppresses
$\mathrm{PGI}_{2} \mathrm{~S}$ gene expression while potently inducing COX-2, $\mathrm{CPLA}_{2}$, and VEGF expression. Pretreatment with potent antioxidants did not alter this imbalance with the exception of $\mathrm{N}$-acetylcysteine (NAC), which reversed the induction of COX-2 by CSE. Conclusions: The main finding of this investigation is the demonstration of decreased $\mathrm{PGI}_{2} \mathrm{~S}$ protein and mRNA in the lungs from patients with emphysema. CSE reduces the expression of the $\mathrm{PGI}_{2} \mathrm{~S}$ gene and increases the expression of VEGF, COX-2, and $\mathrm{CPLA}_{2}$ in HPMVEC. Decreased $\mathrm{PGI}_{2} \mathrm{~S}$ expression is likely multifactorial, including oxidant stress, loss of alveolar capillary endothelial cells, nitric oxide-related suppression, and altered transcriptional control. In vitro work by our laboratory has demonstrated that $\mathrm{PGI}_{2} \mathrm{~S}$ gene expression in lung carcinoma cell lines is partially controlled through methylation silencing. Our demonstration that $\mathrm{PGI}_{2} \mathrm{~S}$ is diminished in both human emphysema tissue and in vitro by CSE, as well as similar observations in carcinomas of the lung, suggest that this imbalance may be an early tobacco smoke-induced event and relevant to the pathogenesis of both diseases.

Conflict of Interest Statement: None of the authors has a financial relationship with a commercial entity that has an interest in the subject of this manuscript.

(Received in original form March 17, 2006; accepted in final form March 28, 2006) Correspondence and requests for reprints should be addressed to $S$. Patrick NanaSinkam, M.D., Division of Pulmonary Sciences \& Critical Care Medicine and COPD Center, University of Colorado Health Science Center, 4200 East Ninth Avenue, Belle Bonfils 3B10, Denver, CO 80262. E-mail: Patrick.nana-sinkam@uchsc.edu Proc Am Thorac Soc Vol 3, 2006 DOI: $10.1513 /$ pats.200603-074MS Internet address: www.atsjournals.org

\section{IFN- $\boldsymbol{\gamma}$-dependent DNA Injury and/ or Apoptosis Are Critical in Cigarette Smoke-induced Murine Emphysema}

\author{
Min Jong Kang, Chun Geun Lee, Soo Jung Cho, Robert J. \\ Homer, and Jack A. Elias
}

Section of Pulmonary and Critical Care Medicine and Department of Pathology, Yale University School of Medicine, New Haven, Connecticut

There is mounting evidence that $\mathrm{Tc} 1$ immune responses contribute to the pathogenesis of pulmonary emphysema. This includes studies demonstrating increased number of IFN- $\gamma$-producing inflammatory cells and increased expression of IFN- $\gamma$ target genes in lungs from patients with chronic obstructive pulmonary disease. Although cigarette smoking is a key risk factor for pulmonary emphysema, the roles of IFN- $\gamma$ and apoptosis in these responses are poorly understood. We hypothesized that IFN- $\gamma-$ dependent apoptosis plays an important role in the pathogenesis of cigarette smoke (CS)-induced murine emphysema. To test this hypothesis, we exposed male C57BL/6 wild-type and IFN- $\gamma$ null $(-/-)$ mice to the CS from $2 \mathrm{R} 4$ research cigarettes, 20 puffs/ session, two sessions/d, $5 \mathrm{~d} /$ wk for 6 mo. Emphysema was then assessed with the NIH Image Analysis program, which provided morphometric measurements of alveolar chord length. DNA injury and apoptosis-like cell death were evaluated with TUNEL assays. After $6 \mathrm{mo}$, the mean chord length was increased by $36.8 \%$ in CS-exposed mice compared with nonsmoking control 